\title{
Coloring of food by the use of natural color extracted by beetroot
} (Beta Vulgaris), betalain pigment.

\section{Coloración de alimentos mediante el uso de color natural extraído de remolacha (Beta vulgaris), pigmento betalaína.}

\author{
Sonika Chaudhary*, Neetu Singh \\ Food Science and Technology, Ambedkar University, Lucknow, India, \\ * Author for correspondence: 01081996sonikac@gmail.com
}

\begin{abstract}
Color is one of the most important quality attributes in the food products. The purpose of adding color in the foods is to make them attractive, to influence the consumer to buy the product and also to improve the quality of the food product. At the present time the demand of natural color is increased in worldwide due to the awareness of people on therapeutic medicinal properties and their benefits in the place of synthetic colors. Synthetic colors are harmful for health and show toxicity in food products. Natural color are those pigments which is derived from naturally sources such as plants, insects, animals, vegetables and fruits etc. among all these natural dyes, plant based pigments have medicinal values so are mostly preferred. Today the food industry are mostly preferred the use of natural coloring pigment in their food products because the generation of this time is very possessive to their health and preferred the food product which is made from the use of natural color. The present study is based on the use of natural colors in food product in the place of synthetic color. The natural color was extracted from beetroot (Beta Vulgaris) named as betalain pigment. Betalain pigment is rich in antioxidant property, vitamin $A$ and $C$ and also a good source of iron, calcium etc. In this experiment the use of the natural color in the preparation of cookies.
\end{abstract}

Keywords: natural food color, dyes, extraction, pigment, beetroot, betalain, cookies.

\section{RESUMEN}

El color es uno de los atributos de calidad más importantes en los productos alimenticios. El propósito de agregar color a los alimentos es hacerlos atractivos, influir en el consumidor 
para que compre el producto y también mejorar la calidad del producto alimenticio. En la actualidad, la demanda de color natural se incrementa en todo el mundo debido a la conciencia de las personas sobre las propiedades medicinales terapéuticas y sus beneficios en lugar de los colores sintéticos. Los colores sintéticos son nocivos para la salud y muestran toxicidad en los productos alimenticios. Los colores naturales son aquellos pigmentos que se derivan de fuentes naturales tales como plantas, insectos, animales, verduras y frutas, etc. Entre todos estos tintes naturales, los pigmentos a base de plantas tienen valores medicinales, por lo que son los más preferidos. Hoy en día, la industria alimentaria prefiere en su mayoría el uso de pigmentos colorantes naturales en sus productos alimenticios porque la generación de este tiempo es muy posesiva para su salud y prefiere el producto alimenticio que se elabora a partir del uso de color natural. El presente estudio se basa en el uso de colorantes naturales en productos alimenticios en lugar de colorantes sintéticos. El color natural se extrajo de la remolacha (Beta Vulgaris) denominada pigmento betalaína. El pigmento betalaína es rico en propiedades antioxidantes, vitamina A y $\mathrm{C}$ y también una buena fuente de hierro, calcio, etc. En este experimento se utilizó el color natural en la preparación de galletas.

Palabras clave: colorante alimentario natural, tintes, extracción, pigmento, remolacha, betalaína, galletas.

\section{INTRODUCTION}

Cookies or biscuits are the largest part of snack item in the bakery products. It is acceptable for both young and elderly people and rich and poor people as a snake due to their low price, shelf-life, easy to eat, easy to carry and also the nutritive value. Cookies is a baked product and easy to digestion. At this time food product industry produce different types of cookies like sugar free cookies, protein enrich cookies etc. in the production of cookies generally three major ingredients are used such as: refined flour, sugar and fat, and some minor ingredients such as flavonoids, additives. Cookies are widely accepted for all profiles of people from many countries and also a good supplementation vehicle for nutritional component. Recently, cookies are prepared from composite flour or fortified with some other good sources of nutrient flour such as whey protein concentrate, wheat germ, oyster mushroom, cassava, and water chestnut flour to improve its nutritional value.

Like several fashionable vegetable, beetroot was $1^{\text {st }}$ cultivated by the Romans within the nineteenth century it command nice business price once it absolutely was discovered that beets may well be regenerate into sugar. Beetroots early charm has resulted in its ubiquitous influence on fashionable menus and recipes. It's delicious but distinctive flavor and nutritional 
status have escalated it to the root you can't beat. It's overpowering color can turn any recipe color in shocking pink.

Beetroot is belonging to the family of Cactaceae and order of Caryophyllales. Belonging to the same family as chard spinach, both the leaves and root can be eaten. Typically an expensive purple color, beetroot also can be white or golden.

Beetroot is becoming popular for its unique shape, attractive red color and high functional properties. In beetroot a pigment is present named as "betalain". The term betalain is come from the Latin name of the common beet (Beta Vulgaris), from which betalain were first extracted. In betalain pigment many nutritional factor and antioxidant factor are present which are used in medicines, food colorant pigment and many other uses. The deep color of beets, bougainvillea, amaranth and many cactuses result from the presence of betalain pigment.

The people have learnt to manage the problem using plants which are gods gifted of nature. Various advances in scientific research on the use of plants and herbs brought the beneficial aspects of traditional medicine and for the coloring pigment.

Color is one of the most important part of the food, being considered as a quality indicator and determining or presenting the food. Therefore, this research was conducted to assess the nutritional composition of cookies incorporated with betalain pigment.

\section{MATERIALS AND METHODS}

Materials: Beetroot was purchased from a local wet market of Lucknow city. The betalain pigment was then extracted as described in next section. Bakery ingredients such as refined flour, sugar, butter, milk or egg, baking powder, sodium chloride salt were procured from local grocery store of the Lucknow city.

Extraction of betalain pigment: Washed the beetroot from the tap water and chopped it very fine and small pieces it. Then, about $300 \mathrm{~g}$ of red beet was mixed in blender with 1.5 liter of ethanol. Ethanol was acidified with $2 \%$ citric acid. The content was mixed for 15 minutes and then was allowed to set for 25 hours. After this the extract was filtered and the liquid pigment was obtained. The obtained pigment was concentrated under vacuum by a rotary vacuum evaporator at $40 \mathrm{C}$ as reported by Francis (2000) and in the last HPLC was used for the identification of pigment.

Cookies preparation: Cookies were prepared according to the normal method with slight modifications. The formula used to produce the cookies is shown in table 1. Betalain pigment 
replaces the synthetic color. Beat the sugar, butter, milk with pigment and other dry ingredients (salt, baking powder) and add the flour to make a dough. Now roll out the dough to a thickness of $1 / 2$ inches and set the rolls in a sequence, cut around with knife in cookies shape. All cookies was baked on greased tray for 12-14 min. at $180 \mathrm{C}$ in an oven. The cookies were cooled at room temperature for $30 \mathrm{~min}$. before packing.

Table 1. Formula for the production of cookies

\begin{tabular}{lc}
\hline \multicolumn{1}{c}{ Ingredients } & Amount $(\mathrm{g})$ \\
\hline Refined flour & 500.0 \\
Sugar & 200.0 \\
Butter & 100.0 \\
Egg & 1.0 \\
Baking powder & 3.5 \\
Sodium chloride salt & 1.0 \\
Betalain pigment & 0.5 \\
\hline
\end{tabular}

\section{RESULT AND DISCUSSION}

After the preparation of cookies. The proximate analyses were performed by the rfrac center (Regional Food Research Center), Lucknow. Rfrac is declared as center of excellence in Food safety, testing, and consultancy as well as HRD purposes by the state government. The nutritional composition of cookies is shown in table 2 .

Table 2. Nutritional value of betalain cookies

\begin{tabular}{llcc}
\hline S.No. & Parameters & Units & Amount \\
\hline 1.$)$ & Moisture & $\%$ & 3.75 \\
2.) & Ash & $\%$ & 1.25 \\
3)$. & Protein & $\%$ & 14.21 \\
4)$. & Carbohydrate & $\%$ & 73.29 \\
5)$. & Total Energy & $\mathrm{K}$ cal & 418 \\
6)$. & Fat & $\%$ & 7.5 \\
\hline
\end{tabular}


The result obtained that the betalain pigment cookies are high in protein and carbohydrate and the color of the cookies is also good and attractive. The use of natural color in food product in the place of synthetic is a good option for food industry and good for human health.

\section{ACKNOWLEDGEMENTS}

I am very happy to express my gratitude to Prof. Sunita Mishra, Dean \& Head, Department of Food Science \& Technology for his kind suggestion and providing me opportunity to work on this project. I am very thankful to my supervisor Dr. Neetu Singh, Assistant Prof. Department of Food Science \& Technology and Dr. Bhawana Dayal. I would like to express my sincere regards and special thanks to research scholars and also to my classmates and friends.

\section{REFERENCES}

Attia, Gamila Y., M.E.M. Moussa and E.R. Sheashea (2013).Characterization of red pigment extracted from red beet (Beta Vulgaris) and its potential uses as antioxidant and natural food colorants, Egypt. J. Agric. Res.,91(3),2013 pp 1095-1113.

Nora M. A1-about. (2018). Effect of red beetroot (Beta Vulgaris L.) intake on the level of some hematological tests in a group of female volunteers", ISABB Journal Of Food And Agriculture Science vol 8(2),pp. 10-17.

Ho \& Abdul Latif (2016). Nutritional composition, physical properties and sensory evaluation of cookies prepared from wheat flour and pitaya (Hylocereus undatus) peel flour blends, Cogent Food \& Agriculture, 2:1136369.

B. Nemzeret al.(2011) Betalainic and nutritional profiles of pigment-enriched red beet root (Beta Vulgaris L.) dried extracts, Food Chemistry, 127(2011) pp 42-53 .

Lundbeg J.O., Weitzberg E., Gladwin M.T. (2008). The nitrate-nitric oxide pathway in physiology and therapeutics". Nat. Rev.;7:156-167 .

Ninfail P., Angelino D.(2013) Nutritional and functional potential of Beta Vulguris cicla and rubra fitoterapia. 89:188-199 .

Strack D, Vogt T, Schliemann W (2003). Recent advances in betalain research. Phytochemistry 62 (3): 247-69 . 
Sustainability, Agri, Food and Environmental Research, (ISSN: 0719-3726), 9(1), 2021: 142-147 http://dx.doi.org/10.7770/safer-VONO-art2017

J. Wruss et al.(2015). Compositional characteristics of commercial beetroot products and beetroot juice prepared from seven beetroot varieties grown in Upper Austria. Journal of Food Composition and Analysis 42: 46-55.

J. Prakash Maran et al. (2013). Modeling and optimization of betalain extraction from Opuntiaficus-indica using Box-Behnken design with desirability function. J Industrial Crops and Products 49: 304- 311.

Received: 19th August 2019; Accepted: 03 ${ }^{\text {th }}$ Jule 2020; Published: 14th September 2020. 